\title{
Metode Pembelajaran Demonstrasi untuk Meningkatkan Kemampuan Ibu dalam Pengelolaan Makanan Bergizi pada Balita Stunting
}

\author{
Zakiyah Yasin, Nelyta Oktavianisya \\ Universitas Wiraraja, Fakultas Ilmu Kesehatan, Program Studi S1 Keperawatan, \\ Jl. Raya Sumenep-Pamekasan KM. 05 Patean, Panitian Utara, Patean, Batuan, \\ Kabupaten Sumenep, Jawa Timur \\ Email: zakiyahfik@wiraraja.ac.id
}

$\begin{array}{ll}\text { Diterima } & : \text { 25 September } 2020 \\ \text { Disetujui } & : 1 \text { November } 2020 \\ \text { Dipublikasikan } & : \text { 10 Desember } 2020\end{array}$

\begin{abstract}
Abstrak
Latar Belakang: Stunting merupakan salah satu indikator keberhasilan kesejahteraan masyarakat. Dampaknya sangat luas mulai dari ekonomi, kecerdasan dan kualitas, yang berefek pada masa depan anak. Kejadian Stunting pada balita dikarenakan kurang memperhatikan status gizi dan pengelolahannya. Status gizi memiliki pengaruh yang sangat besar dalam mewujudkan sumber daya manusia yang berkualitas di masa yang akan datang. Permasalahan status gizi pada balita masih jadi pekerjaan rumah dan tantanga, setiap daerah juga bersamasama mengentaskan masalah ini. Tujuan penelitian ini adalah menganalisis apakah metode pembelajaran demonstrasi dapat meningkatkan kemampuan ibu dalam mengelola makanan bergizi.

Metode: Jenis penelitian ini adalah quasy-experiment, pretest-posttest control group design. Rancangan ini berupaya untuk mengungkapkan hubungan sebabakibat dengan cara melibatkan kelompok kontrol dan kelompok eksperimental. Penelitian dilakukan di UPT Puskesmas Dungkek dengan sampel berjumlah 40 responden. Uji statistik menggunakan independent sample T Test.

Hasil: Nilai signifikan $\rho$ Value $=0,000$ dengan $\alpha=0,05$. Karena $\rho$ value $<\alpha$ maka ada pengaruh metode demontrasi terhadap peningkatan kemampuan ibu dalam pengelolaan makanan bergizi.

Simpulan dan Implikasi: Metode pembelajaran demonstrasi dapat meningkatkan kemampuan ibu dalam mengelola makanan yang bergizi untuk balita stunting. Dengan demikian maka intervensi ini dapat diberikan oleh petugas kesehatan sebagai salah satu bentuk penanganan stunting pada balita.
\end{abstract}

Kata Kunci: Balita; Demontrasi; Gizi; Ibu; Stunting

Sitasi: Yasin Z \& Oktavianisya N. (2020). Metode pembelajaran demonstrasi untuk meningkatkan kemampuan ibu dalam pengelolaan makanan bergizi pada balita stunting. The Indonesian Journal of Health Science. 12(2), 130-136

Copyright: (c) 2020 Rusdianingseh et al. This is an open-access article distributed under the terms of the Creative Commons Attribution-NonCommercial 4.0 International License, which permits unrestricted use, distribution, and reproduction in any medium, provided the original author and source are credited.

Diterbitkan Oleh: Universitas Muhammadiyah Jember

ISSN (Print): 2087-5053

ISSN (Online): 2476-9614 


\begin{abstract}
Background: Stunting is an indicator of the success of community welfare. The impact is very wide ranging from economy, intelligence and quality, which have an effect on the future of the child. The incidence of stunting in children under five is due to lack of attention to nutritional status and management. Nutritional status has a very big influence in creating quality human resources in the future. The problem of nutritional status in children under five is still a chore and a challenge, each region also jointly eliminates this problem. The purpose of this study was to analyze whether demonstration learning methods could improve mothers' ability to manage nutritious food.
\end{abstract}

Methods: Research design used quasy-experiment, pretest-posttest control group design. This design seeks to reveal causal relationships by involving a control group and experimental group. The research was conducted at UPT Puskesmas Dungkek with a sample of 40 respondents. Statistical test was used independent sample T Test.

Results: The results of the posttest-posttest data analysis in the treatment group and the control group using the Independent Sample T Test showed a significant value of $\rho$ Value $=0.000$ with $\alpha=0.05$. Because $\rho$ Value $<\alpha 0,05$, there is an effect of giving the demonstration method on increasing the ability of mothers in managing nutritious food.

Conclusion: Demonstration learning methods can improve the ability of mothers to manage nutritious foods for stunting toddlers. Thus, this intervention can be provided by health workers as a form of handling stunting in toddlers.

Keywords: Demonstration; Mother; Nutrition; Stunting; Toddler

\section{PENDAHULUAN}

Kondisi gizi dan permasalahan gizi pada hakikatnya merupakan kesehatan masyarakat yang proses penanggulangannya tidak dapat dilakukan hanya dengan pendekatan medis ataupun pelayanan kesehatan yang ada pada masyarakat. Permasalahan gizi sering terjadi yang di akibatkan dengan kebiasaan hidup yang kurang baik, karena masyarakat masih banyak yang kurang memikirkan nilai-nilai gizi. Berdasarkan salah satu penelitian yang telah terdahulu mengenai permasalahan status gizi di Indonesia dengan indikator berat badan per umur $(\mathrm{BB} / \mathrm{U})$, adalah sebanyak $18,4 \%$, dari angka tersebut bisa dibilang cukup tinggi (Apriluana \& Fikawati, 2018).
Kejadian gizi buruk di Jawa Timur sebesar 4,8\%, gizi kurang sebesar 12,3\% (Dewi \& Budiantara, 2012). Hal tersebut menunjukkan masih rendahnya pelayanan pada masalah kesehatan yang berkaitan dengan bayi dan anak balita yang lebih di khususkan pada masalah gizi. Kasus tersebut terjadi pula pada Kabupaten Sumenep yang di atas angka Nasional maupun Jawa Timur, yaitu $8,6 \%$ untuk terjadinya gizi buruk dan 20,9\% untuk jumlah gizi kurang (Hidayat \& Fuada, 2011). Permasalahan gizi yang terjadi pada masyarakat dapat dipengaruhi dengan beberapa faktor, yaitu diantaranya pengolaan makanan yang benar, yang menjadi penyebab utama, kondisi makanan yang tidak seimbang dapat mempengaruhi 
asupan gizi dan mutu gizi (Sholikah, et.al, 2017). Asupan zat gizi sangat penting dan apabila zat gizi sudah tidak dapat di cerna oleh tubuh secara optimal, bisa saja ada gangguan yang di sebabkan adanya penyakit infeksi (Mugianti, et.al, 2018), selain itu adanya penyebab di atas, kurangnya persediaan pangan di rumah tangga, proses pengasuhan pada anak yang kurang baik khususnya pada pemberian makan anak (Ni'mah \& Nadhiroh, 2015). Dengan demikian, penanganan permasalahan gizi di Kabupaten Sumenep khususnya Kecamatan Dungkek, bukan hanya berdampak kepada kesehatan masyarakat kelas menengah ke bawah, akan tetapi bisa diminimalisir, sehingga kesehatan masyarakat bisa terjamin dengan cara memberikan edukasi cara pengelolaan makanan bergizi yang benar. Dengan demikian maka tujuan penelitian ini untuk melihat pengaruh pembelajaran demonstrasi dalam meningkatkan kemampuan ibu dalam pengelolaan makanan bergizi.

\section{METODE PENELITIAN}

Rancangan penelitian yang digunakan, yaitu quasy-experiment, pre test-post test control group design. Rancangan ini berupaya untuk mengungkapkan hubungan sebab-akibat dengan cara melibatkan kelompok kontrol di samping kelompok eksperimen. Pada kedua kelompok diawali dengan pembagian koesioner sebelum diberikan perlakuan (pretest). Kelompok intervensi diberikan perlakuan sedangkan kelompok kontrol tidak diberi perlakuan. Kemudian setelah dilakukan perlakuan dilakuan pembagian kuesioner kembali untuk melihat peningkaytan kemampuan ibu dalam pengelolaan makanan bergizi (posttest) untuk mengetahui pengaruh dari perlakuan.

Penelitian ini dilaksanakan di wilayah kerja UPT. Puskesmas Dungkek Kecamatan Dungkek Kab. Sumenep dengan melibatkan ibu yang memiliki anak yang mengalami stunting dan berada di wilayah kerja UPT. Puskesmas Dungkek Kecamatan Dungkek Kab. Sumenep dengan instrumen pengambilan data yaitu kuesioner. Untuk mengetahui pegaruh metode demonstrasi dalam meningktkan kemampuan ibu dalam pengelolaan makana bergizi dilakukan pengujian statistik dengan menggunakan Uji T.

\section{HASIL}

\section{Karakteristik Responden}

Table 1 menunjukkan bahwa karakteristik responden berdasarkan tinggi badan pada kelompok perlakuan sebanyak 11 anak $(55 \%)$ memiliki tinggi badan sangat pendek, dan 9 anak (45\%) memiliki tinggi badan pendek, sedangkan pada kelompok kontrol sebanyak 12 anak $(60 \%)$ memiliki tinggi badan sangat pendek, dan 8 anak (40\%) memiliki tinggi badan pendek.

Karakteristik berdasarkan tingkat pendidikan diketahui pendidikan ibu pada kelompok perlakuan terbanyak adalah SMA dengan 10 orang $(50 \%)$, sedangkan terkecil adalah tingkat SMP dengan 3 orang $(15 \%)$ sedangkan 7 orang (35\%) berpendidikan SD. Pada kelompok ontrol terbanyak adalah SMA dengan 8 orang (40\%), sedangkan tingkat SMP dan SD dengan 6 orang (30\%) (Tabel 2).

Karakteristik pendapatan keluarga berdasarkan tabel 4 diketahui bahwa pendapatan keluarga pada kelompok perlakuan 
terdapat 18 orang $(90 \%)$ di bawah 1.500.000, sedangakan 2 orang $(10 \%)$ di atas 1.500.000. pada kelompok kontrol didapat sebanyak 18 orang (90\%) di bawah 1.500.000, sedangkan 2 orang $(10 \%)$ di atas 1.500.000.

\section{Hasil Analisis}

Tabel 5 menunjukkan distribusi frekuensi nilai kemampuan ibu dalam pengelolaan makanan bergizi sebelum dan sesudah dilakukan demontrasi pada kelompok perlakuan dan kontrol. Sebagian besar ibu memiliki kemampuan dalam pengelolaan makanan bergizi setelah pemberian demontrasi (perlakuan) sebesar 43,85\% pada kemampuan pre dan $58,20 \%$ pada saat kemampuan post.

Berdasarkan tabel 6 diketahui hasil analisis data pretest-pretest kemampuan ibu dalam pengelolaan makanan bergizi pada kelompok perlakuan dan kelompok control menggunakan uji Independent Samples $T$ Test didapatkan nilai $\rho$
Value $=0,877$ dengan $\alpha=0,05$. Karena $\rho$ Value $>\alpha$ maka tidak ada beda kemampuan ibu dalam pengelolaan makanan bergizi pada pretest pada kelompok kontrol.

Hasil analisis data pretestposttest kemampuan ibu dalam pengelolaan makanan bergizi pada kelompok perlakuan menggunakan uji Paired Samples T Test didapatkan nilai $\rho$ Value $=0,000$ dengan $\alpha=$ 0,05 . Karena $\rho$ Value $<\alpha$ maka ada perbedaan antara sebelum dan sesudah demontrasi terhadap peningkatan kemampuan ibu dalam pengelolaan makanan bergizi. Sedangkan hasil analisis data pretestposttest kemampuan ibu dalam pengelolaan makanan bergizi pada kelompok kontrol menggunakan uji Paired Samples $T$ Test didapatkan nilai $\rho$ Value $=0,337$ dengan $\alpha=$ 0,05 . Karena $\rho$ Value $>\alpha$ maka pada kelompok yang tidak mendapatkan perlakuan demontrasi, tidak ada beda antara sebelum dan sesudah perlakuan.

Tabel 1. Distribusi Responden Berdasarkan Tinggi Badan ( $\mathrm{n}=40)$

\begin{tabular}{lcccc}
\hline \multirow{2}{*}{ Tinggi Badan } & \multicolumn{2}{c}{ Kelompok Perlakuan } & \multicolumn{2}{c}{ Kelompok Kontrol } \\
\cline { 2 - 5 } & $\mathrm{F}$ & $\%$ & $\mathrm{~F}$ & $\%$ \\
\hline Pendek & 9 & 45 & 8 & 40 \\
Sangat Pendek & 11 & 55 & 12 & 60
\end{tabular}

Tabel 2. Distribusi Responden Berdasarkan Pendidikan Ibu

\begin{tabular}{ccccc}
\hline Pendidikan Ibu & \multicolumn{2}{c}{ Kelompok Perlakuan } & \multicolumn{2}{c}{ Kelompok Kontrol } \\
& F & $\%$ & F & $\%$ \\
\hline SD & 7 & 35 & 6 & 30 \\
SMP & 3 & 15 & 6 & 30 \\
SMA & 10 & 50 & 8 & 40 \\
\hline
\end{tabular}

Tabel 3.Distribusi Responden Berdasarkan Pendapatan Keluarga ( $\mathrm{n}=40)$

\begin{tabular}{lcccc}
\hline \multirow{2}{*}{ Pendapatan Keluarga } & \multicolumn{2}{c}{ Kelompok Perlakuan } & \multicolumn{2}{c}{ Kelompok Kontrol } \\
& $\mathrm{F}$ & $\%$ & $\mathrm{~F}$ & $\%$ \\
\hline < Rp. 1.500 .000 & 18 & 90 & 18 & 90 \\
$\geq$ Rp. 1.500 .000 & 2 & 10 & 2 & 10
\end{tabular}


Tabel 4. Distribusi Frekuensi Nilai Kemampuan Ibu dalam Pengelolaan Makanan Bergizi Sebelum dan Sesudah dilakukan demontrasi pada Kelompok Perlakuan dan Kontrol

\begin{tabular}{llccccc}
\hline & & n & Min & Maks & Mean & Std. Deviation \\
\hline Perlakuan & $\begin{array}{l}\text { Kemampuan } \\
\text { _Pre }\end{array}$ & 20 & 31 & 66 & 43,85 & 13,26 \\
\hline $\begin{array}{l}\text { Kemampuan } \\
\text { Kontrol }\end{array}$ & 20 & 36 & 68 & 58,20 & 7,26 \\
& $\begin{array}{l}\text { Kemampuan } \\
\text { _Pre }\end{array}$ & 20 & 31 & 60 & 43,20 & 10,87 \\
& $\begin{array}{l}\text { Kemampuan } \\
\text { _Post }\end{array}$ & 20 & 31 & 60 & 42,95 & 10,45 \\
\hline
\end{tabular}

Tabel 5. Distribusi Hasil Uji Kemampuan Pengelolaan Makanan Bergizi pada Kelompok Perlakuan dan Kelompok Kontrol Setelah dan Sebelum Intervensi

\begin{tabular}{ccccc}
\hline \multirow{2}{*}{$\begin{array}{c}\text { Kelompok } \\
\text { Responden }\end{array}$} & $\begin{array}{c}\text { Pretest- } \\
\text { Pretest }\end{array}$ & $\begin{array}{c}\text { Pretest- } \\
\text { Posttest }\end{array}$ & $\begin{array}{c}\text { Pretest- } \\
\text { Posttest }\end{array}$ & $\begin{array}{c}\text { Posttest- } \\
\text { Posttest }\end{array}$ \\
\cline { 2 - 5 } & $\begin{array}{c}\text { Perlakuan- } \\
\text { Kontrol }\end{array}$ & Perlakuan & Kontrol & $\begin{array}{c}\text { Perlakuan- } \\
\text { Kontrol }\end{array}$ \\
\hline $\begin{array}{c}\text { Nilai Sig } \\
(\rho V a l u e)\end{array}$ & 0,877 & 0,000 & 0,337 & 0,000 \\
\hline
\end{tabular}

\section{PEMBAHASAN}

Hasil penelitian menunjukkan bahwa metode pembelajaran demonstrasi dapat meningkatkan kemampuan ibu dalam mengelola makanan bergizi bagi balita stunting. Balita stunting memerlukan makanan yang bergizi dan beraneka ragam. Makanan beraneka ragam sangat diperlukan dalam pertumbuhan balita stunting. Makan makanan beraneka ragam berfungsi sebagai sumber energi, membantu pertumbuhan badan, memelihara jaringan tubuh serta mengganti sel yang rusak, mengatur metabolisme serta pertahanan tubuh terhadap penyakit (Departemen Gizi dan Kesehatan Masyarakat, 2011).

Berdasarkan pola pemberian makan dapat dilihat bahwa kejadian stunting sebagian besar menunjukan bahwa balita mendapatkan pemberian makan tidak baik. Sebagian besar ibu memiliki kemampuan dalam pengelolaan makanan bergizi setelah pemberian demontrasi (perlakuan) sebesar $43,85 \%$ pada kemampuan pre dan $58,20 \%$ pada saat kemampuan post. Hal ini membuktikan bahwa ibu yang diberi ilmu pengetahuan akan berbeda perlakuannya dari pada ibu yang tidak memiliki ilmu pengetahuan. Hasil penelitian ini sejalan dengan penelitian di Kabupaten Sumba Tengah Nusa Tenggara Timur oleh Loya dan Nuryanto (2017) yang menyatakan bahwa pemberian makan menjadi salah satu faktor risiko terjadinya stunting, hal ini dikarenakan pemberian menu makan yang monoton setiap hari dan tidak bervariasi serta kurangnya pengetahuan seorang ibu dalam pemenuhan gizi anak menjadi hal yang paling menentukan. 
Kemampuan ibu dalam mengelola makanan bergizi tidak lepas dari pemberian metode demostrasi. Metode demonstrasi membawa proses perubahan perilaku kearah yang diharapkan melalui peran aktif sasaran. Dalam penelitian ini menunjukkan bahwa ada pengaruh pemberian demontrasi terhadap peningkatan kemampuan ibu dalam pengelolaan makanan bergizi. Hal ini di perkuat oleh penelitian Noviati (2011) yang menyatakan bahwa ada pengaruh penyuluhan dengan metode demonstrasi dan praktik memberikan manfaat yang lebih baik terhadap perubahan pengetahuan dan praktik dibanding hanya dengan penyuluhan saja.

Metode demonstrasi adalah menunjukkan kepada peserta cara melakukan, membuat sesuatu, atau menggunakan sesuatu. Demonstrasi biasanya diikuti dengan kegiatan bersama oleh sebagian peserta atau seluruhnya dengan tujuan untuk mengajarkan secara nyata bagaimana melakukan, membuat sesuatu, atau meggunakan sesuatu dan menunjukkan cara-cara atau prosedur dengan teknik-teknik yang baru dan benar. Teknik ini lebih efektif karena menggunakan praktik secara langsung sehingga intruksi lebih capat diterima oleh peserta.

\section{SIMPULAN}

Ada pengaruh metode demontrasi terhadap peningkatan kemampuan ibu dalam pengelolaan makanan bergizi. Kemampuan ibu dalam mengelola makanan bergizi tidak lepas dari pemberian metode demostrasi. Metode demonstrasi membawa proses perubahan perilaku kearah yang diharapkan melalui peran aktif sasaran.

\section{SARAN}

Diharapkan keluarga terutama ibu memberikan nutrisi yang adekuat kepada anak sesuai umur, sehingga dapat mencegah stunting. Hendaknya ibu yang memiliki anak stunting melakukan perbaikan gizi pada anak dengan mengikuti semua anjuran tenaga kesehatan dan kader posyandu, memberikan. Sedangkan untuk tenaga kesehatan diharapkan dapat menggunakan metode demonstrasi ini dalam memberikan intervensi kepada ibu dalam meningkatkan status gizi balita stunting.

\section{DAFTAR PUSTAKA}

Apriluana G \& Fikawati S. (2018). Analisis faktor-faktor risiko terhadap kejadian stunting pada balita (0-59 bulan) di negara berkembang dan asia tenggara. Media Litbangkes, 28(4), 247 256.

Dewi, R K \& Budiantara I N. (2012). Faktor-faktor yang mempengaruhi angka gizi buruk di jawa timur dengan pendekatan regresi nonparametrik spline. Jurnal Sains dan Seni Its. 1(1), 177-182.

Hidayat, T \& Fuada, N,. (2011). Hubungan sanitasi lingkungan, morbiditas dan status gizi balita di indonesia (relationship between environmental sanitation, morbidity and nutritional status of under-five children in indonesia). 34, 104113.

Loya, R. R. P. and Nuryanto N. (2017). Pola asuh pemberian 
makan pada bayi stunting usia 612 bulan di Kabupaten Sumba Tengah, Nusa Tenggara Timur. Journal of Nutrition College, vol. 6, no. 1, pp. 84-95, https://doi.org/10.14710/jnc.v6i1 .16897

Ni'mah K \& Nadhiroh S. R. (2015). Faktor yang berhubungan dengan kejadian stunting pada balita. Media Gizi Indonesia, 10(1), 13-19.

Noviati. (2011). Pengaruh penyuluhan dengan metode demonstrasi dan praktek terhadap pengetahuan ibu dan asupan gizi kurang di RSPAD Gatot Soebroto Jakarta. Jurnal Ilmu Kesehatan Gizi, 2(2), 1-53. Mugianti S, Mulyadi A, Anam A K, \& Najah Z. L (2018). Faktor penyebab anak stunting usia 2560 bulan di Kecamatan Sukorejo Kota Blitar. Jurnal Ners dan Kebidanan, 5(3), 268-278.

Sholikah A, Rustiana E R, \& Yuniastuti A. (2017). Faktorfaktor yang berhubungan dengan status gizi balita di pedesaan dan perkotaan. Public Health Perspective Journal 2 (1), 9 18. 